I I UC STUDI ES

ISSN 1813-7733

Vol. - 3, December 2006 (p 31-44)

\title{
'Frailty, Thy Name is Woman' - How Frail are Women in the World of Shakespeare?
}

\author{
Muhammad Safiur Rahman*
}

\begin{abstract}
This paper attempts to understand a remarkable point whether we can argue, quoting Hamlet's remark 'frailty, thy name is woman', that Shakespeare is a misogynist. With that end in view it analyses the situations which lead Hamlet to hold a special kind of prejudice against women. Hence, it examines the justification of his misogynistic remarks in the play. Here the chief concern is whether it is Shakespeare's viewpoint or the view of his character Hamlet; and whether it is deep-rooted, well-thought one or momentary one. Some women characters in several other plays of Shakespeare have been studied, in an endeavor to compare their roles, and to see whether they all show weakness, or some of them surpass the male characters around them in their respective plays. The focus has always been simply on the point whether women are generally frail in the world of Shakespeare. The paper concludes that Hamlet's view does not represent the general view of women in Shakespearean literature; rather it is a sweeping generalization of the misogyny of a young man who has, somehow, been betrayed by women in his life.
\end{abstract}

Hamlet, in some of his remarks, shows strong prejudice against woman. The immediate cause for this negative attitude is the activities of Gertrude, his own mother. We first see him in deep melancholic mood, as if he seems to have lost all sense of interest in life. The sudden death of his father and the disgust at the quick second marriage of his mother contribute considerably to his miserable condition. But, it seems that he attaches much more importance to the second one. Wilson Knight says:

"Of his two loved parents, one has been taken forever by death, the other dishonoured forever by her act of marriage. ..... He suffers from misery at his father's death and agony at his mother's quick forgetfulness". ${ }^{1}$

From the very first appearance, Hamlet consciously keeps himself totally aloof from both Gertrude and Claudius. Indeed, he does not have any communication, outward or emotional, with anyone present there. Only he is wearing black clothes to mourn his father's death. Claudius mentions it as only clouds ['the clouds still hang on you' I. ii. 66] and Gertrude as only 'nighted colour' ['cast your nighted colour off' I. ii. 68]. Here the remark of Gertrude appears to be the echo of Claudius’s comment.

Although both Gertrude and Claudius show coldness to the memory of the late king by asking Hamlet not to mourn so long, their purposes are different. Claudius does so because he wants Hamlet to take his father's death as a natural one, so that he does not probe the matter. Being the murderer, naturally he is afraid of Hamlet's attaching excessive importance to it. So he tries to convince Hamlet that this is nothing particular to him, rather it is a common happening in human life:

"But you must know your father lost a father, That father lost, lost his and the survivors bound In filial obligation for some term”.

(I. ii. $89-91$ )

* Lecturer, Dept. ofEnglish Language \& Literature, International Islamic University Chittagong. 


\section{IIUC Studies, Vol. 3}

Gertrude, being a mother, also attaches more importance to Hamlet's returning to normalcy, because she is more anxious about the health of her son than the memory of her late husband. Here she, however passionate she is to Hamlet, pathetically fails to understand the real motive in his prolonged mourning, and give him any emotional support that he desperately requires at this critical moment. Moreover, she has already weakened her credibility to him because of her second marriage. She completely fails to realize that her 'hasty marriage' has made Hamlet sadder than the death of his father.

Since Hamlet already harbors a secret suspicion about Claudius's involvement in his father's death, he shows a total indifference to Claudius ['A little more than kin but less than kind"2. I. ii. 65] Again, after being informed by Horatio about the appearance of the ghost, he says, "All is not well / I doubt some foul play”(I. i. 260-1). And yet again, after the revelation of the ghost, he refers to this earlier suspicion ' $\mathrm{O}$ my prophetic soul! My uncle'(I. v. 42). At this stage, what makes the situation worse is that Gertrude advocates Hamlet to be friendly to Claudius- "And let thine eye look like a friend on Denmark" (I. ii. 69). Clearly, here her sympathy goes to her second husband, instead of going to her bereaved son. It widens his emotional distance from his mother.

Again, while Hamlet is terribly disgusted by her coldness to the memory of the late king, exhibiting her poor understanding of his real sentiment, she asks him to accept the death of his father as a natural phenomenon. Apparently it sounds quite convincing. But, ironically, she herself fails to react naturally at the death of her husband, and to sympathize with her mourning son. Moreover, less than two months' mourning seems to her as mourning 'forever'. Claudius also echoes Gertrude. To him Hamlet's mourning is tantamount to 'obstinate, impious stubbornness, unmanly grief'(I ii 93) - which is incorrect to heaven. Instead of taking the death of his father 'to heart', he advises, Hamlet should "throw this unprevaling woe'(I ii 107) 'to earth', and should think of Claudius 'as of a father'(I ii 108). He almost allures him:-

"And let the world take note,

You are the most immediate to our throne".

I ii 109

Here Claudius shrewdly tries to create an impression that he is absolutely benevolent to his nephew. But Hamlet knows that Claudius's gesture of affection is not real, so it does not create any appeal to him. Claudius is reluctant to allow Hamlet to go back to Wittenberg because he wants to keep him under his constant surveillance so that he can avoid a possible future political threat from the latter. So, he tries to allure Hamlet with every possible means to remain in Denmark:

"And we beseech you bend you to remain

Here in the cheer and comfort of our eye,

Our chiefest courtier, cousin, and our son"

I. ii. $115-7$

Without realizing Claudius's purpose, socked with emotion Gertrude immediately seconds the proposal showing her poor intellectuality:

"Let not thy mother lose her prayers, Hamlet, I pray thee, stay with us, go not to Wittenberg."

I. ii. $118-9$ 
'Frailty, Thy Name Is Woman' - How Frail are Women in the World of Shakespeare?

Hamlet observes all these things so far. When everyone else leaves the stage, in his first soliloquy he speaks his mind loudly. He abhors his mother's overhasty marriage, ignoring the 'green' memory of his father's death, and more terribly the degradation of her, in marrying such a man who is in no way comparable to his father in the remotest possible way. To him, his father was a person comparable to the celestial figure - Hyperion, and in sharp contrast, Claudius is only a lecherous creature - satyr. Peter D. Holland observes:- "To Hamlet his father and Claudius typify what is best and worst in humanity". ${ }^{3}$ Moreover, at that time, the marriage of a man to his deceased brother's wife was considered incestuous. This is not simply an overhasty marriage, to her deceased husband's brother: Peter again says:-

".....this is serious enough, to be sure, for it violates a taboo ( parallel to the marriage of a widower to his deceased wife's sister, long regarded as incestuous by the English") and is thus understandably referred to as 'incest' by Hamlet and his father's ghost. The appalling spectacle .............. overwhelms Hamlet with revulsion at carnal appetite and intensifies the emotional crisis any son would go through when forced to contemplate his father's death and his mother's remarriage" ${ }^{4}$

Hamlet wants to find some explanation for his mother's attachment to Claudius. To his utter dismay, failing to understand that his mother is more a simpleton than a lustful woman, he finds her as a lusty woman and a negligent mother. He expects his mother to be a weeping widow at the irreparable loss in her life as well as in his own, but he does not find her so. Finding no other explanation to his mother's behavior, he starts to believe that she places her carnal desire above her love and affection for him and his father. This misunderstanding of his mother creates and develops in Hamlet's mind a profound dislike for women. He thinks it is the common weakness of women folk that leads her to these abominable activities. Interestingly, here the reason appears to Hamlet is 'frailty'weakness, not wickedness. ${ }^{5}$

What particularly darkens Hamlet's view of woman, and prompts him to come to a generalized conclusion, however, is not his first-hand knowledge of many women. In the play he encounters only two women-Gertrude and Ophelia. When he starts thinking 'woman' and 'weakness' as synonymous, only Gertrude is at the back of his mind. Even it is before he encounters Ophelia's forced rejection of his love. Though he is an unmarried young prince of thirty, who is likely to have many female friends, the play does not give any evidence of his relationship with any women other than these two. He observes that both Gertrude and Ophelia show several types of weaknesses, of course in varied degrees. Gertrude does not understand the wicked tricks Claudius plays upon her, nor does she understand Hamlet's ulterior motive behind his prolonged mourning and deliberate aloofness from his uncle's company. She is not even a proper match for her late husband. Despite all her weaknesses that bring about her defeat at the hands of Claudius, the ghost still loves her. He asks Hamlet not to misbehave with her. But there is no such feeling in the Queen. In her bedchamber she does not see the ghost, because she does not have any love left for the late king. Only Hamlet can see it as he is still emotionally attached to his father. ${ }^{6}$

It is true that Gertrude lacks in common sense. She is an utter failure in understanding human nature. She is only a puppet guided by Claudius in all affairs. So is Ophelia, even in her love affair she is guided by her father and brother. She does not understand that she is a play-thing in the hands of her father who is appointed by Claudius to discover the true cause of Hamlet's madness. She does not 


\section{IIUC Studies, Vol. 3}

betray any independence of thinking, rather shows her foolish submissiveness to her brother's and father's instructions in regard to her relationship with Hamlet. Without any protest she allows herself to be used by Polonius and Claudius as a 'decoy' against Hamlet.7 To his acute disappointment, Hamlet painfully perceives it. That is why he rushes to Ophelia's private chamber in a frightful appearance, to inspect her face closely, just to authenticate his perception. Certainly, it contributes a lot to intensify his already negative attitude towards woman, formed by the way his mother behaves. Here Ophelia is much like Gertrude, earlier the queen surrendered to Claudius's 'importunity' without ever questioning the motive of the latter. Peter comments:-

"The resemblance between Ophelia and Gertrude conforms Hamlet's tendency to generalize about famine weakness 'frailty, thy name is woman' and prompts his misogynistic outburst against Ophelia....." 8

At a very psychologically critical moment, Ophelia's returning his love-tokens makes Hamlet feel more miserable. It is too great a shock for him from his beloved to bear. In the true sense, she is the last emotional resort for Hamlet in the crucial situation he faces at the moment. But she fails to come up with the required support to Hamlet, rather helplessly submits herself to the will of her father. So, losing his last touch with life, he behaves ruthlessly with Ophelia. Wilson Knight says:-

"Hamlet's soul is sick to death - and yet there was one thing left that might have saved him. In the deserts of his mind, void with the utter vacuity of the knowledge of death - death of his father, death of his mother's faith-was yet one flower, his love of Ophelia. ......The love of Ophelia is thus Hamlet's last hope. This, too, is taken from him”. 9

Both Gertrude's and Ophelia’s behavior make Hamlet believe that woman's love is very 'brief'. In fact, 'brief' and 'woman's love' become synonymous to him- (III ii 151)

From another perspective we understand that his misogynistic attitude is not innate, nor is his melancholic attitude towards life. Earlier he was a happy person, a student of a prestigious university, studying philosophy. His life was peaceful at that time. Later Claudius refers to it as 'all his days of quiet' (III i 3). He developed a very healthy relationship with Ophelia in an 'honuorable fashion'. (I iii 111-2). Not only that, he had a positive artistic mind, and he used to enjoy theatrical performance. He immediately recognizes the players and becomes over delighted at the news of their arrival. Still he can write lines to insert into a play, and give directions, like a skilled director, to the professional actors in stage performance. Indeed, in the presence of the players we have a glimpse of Hamlet's real disposition although only for a short while: A. C. Bradley says:-

"In his instructions to the actors on the delivery of the inserted speech, and in his conversation with Horatio just before entry of the court, we see the true Hamlet - the Hamlet of the days before his father's death.”10

These things indicate his having been actively cultural in the past. But some sudden and sheer unexpected events have totally turned every thing in his life upside down. 
Despite all his negative remarks, Hamlet is not a woman-hater. Although he accuses his mother of being 'frail', he is terribly aware that he loves and respects her very deeply. His attitudes towards Claudius and towards Gertrude are not the same. Being sent for by his mother, when he is going to her bed-chamber, he sincerely prays to have strength enough not to lose self-control in her presence and use the dagger on her:

"O heart, lose not thy nature; let not ever The soul of Nero enter this firm bosom ${ }^{11}$,

III ii 392-3

He believes that only part of the heart of his mother is 'worser', but half is still 'purer'; and she can live with it. He urges her only to keep away from Claudius. Even in the revelation of the ghost, we notice that the late king blames Claudius more than Gertrude for their adulterous relationship.

“.. That incestuous beast, that adulterate beast, With witchcraft of his wit, with traitorous giftOh, wicked wit and gifts, that have the power So to seduce! Won to his shameful lust The will of my most seemingly virtuous queen.”

(I. v. 43- 48)

We find a sense of love in the king's softer tone. He still does not consider his wife as wicked. Instead, he thinks, it is her weakness and inability to understand the wicked motif of Claudius that misled her. So he asks Hamlet not to misbehave with the Queen.

"But, howsomever thou pursue this act,

Taint not thy mind nor let thy soul contrive Against thy mother aught.

(I. v. $85-90)$

Again, after two months of his generalized comment on 'woman's frailty', (in act III scene I), at the sight of Ophelia, Hamlet utters to himself:-

"The fair Ophelia-Nymph, in thy orisons

Be all my sins remembered.”

(III i 90-1)

In this remark we hear the voice of an ardent lover; certainly the voice is not that of a misogynist. He spontaneously uses the adjective 'fair' and Ophelia is still 'Nymph' to him. So clearly behind his apparent cruelty, Hamlet is very kind-hearted towards both Ophelia and his mother. He uses his cruelty only to awaken them to the terrible situations which they are in. He is 'cruel' only to be 'kind'; only to make them see "the inner most part.”

(III iv 21).

Again, we find in Hamlet a profound sense of love for Ophelia, at the very core of his heart, despite all his bitter remarks, in his utterance of these heart-felt lines-

"I loved Ophelia. Forty thousand brothers Could not with all their quantity of love Make up my sum.” 


\section{IIUC Studies, Vol. 3}

Serajul Islam Choudhury aptly says:- "This is not the empty boast of an overexcited man, rather the frank confession of a passionate lover" ${ }^{12}$

Unlike Gertrude, Ophelia shows some strength in her character. She is not totally a weak character. But she is placed in a very difficult situation. Peter D. Holland says:-

"Ophelia is an innocent young woman and enjoys our sympathy. She is really very affectionate towards Hamlet. But she falls between the conflicting wills of her brother, her father and her lover-all of them are very important to her". ${ }^{13}$

She protests Leartes's misinterpretation of Hamlet's attitude towards her-- 'No more but so?'

These four words connote much more than they denote. Her proper understanding of Hamlet's sincerity makes her retort the irresponsible remarks of her brother. However submissive may she be to her father, she retaliates the verbose advice of her irresponsible brother:

" but, good my brother,

Do not, as some ungracious pastors do, Show me the steep and throny way to heaven, Whiles like a puffed and reckless libertine Himself the primrose path of dalliance treads, And rocks not his own rede.”

I. iii. 4651

Ophelia has a keen perception, she understands many things, but she cannot express. Because, the patriarchy of the age does not allow her to go beyond a certain level. Peter thinks:-

"Obedient by instinct and training to patriarchal instruction, she is unprepared to cope with divided authority and so takes refuse in passivity. Nevertheless, her pitiable story suggests that weak-willed acquiescence is poisoned by the evil to which it surrenders". ${ }^{14}$

We find in her a profound sense of pity for Hamlet at the sight of his distressed condition:-

“Oh, what a noble mind is here o'erthrown!

The courtier's, soldier's, scholar's, eye, tongue, sword,

The expectancy and rose of the fair state,

The glass of fashion and the mold of form,

Th' observed of all ovservers, quite, quite, down”

III.i.153- 158

In this play, Ophelia is the second tragic character. Although, Shakespeare does not make her the protagonist of the play, he places her beside Hamlet in her tragic appeal, who wins our pity. Indeed, apart from Horatio, only Ophelia could properly evaluate Hamlet. ${ }^{15}$

Gertrude also has something to say. We must hear it. If we evaluate her based on only what the male characters say about her, we will have only an inaccurate picture of her. 
"The essential Gertrude can be properly recognized from an analysis of the words she herself speaks - rather than the things said about her by the ghost and by Hamlet”. ${ }^{16}$

There is a 'real Gertrude' for whom Smith speaks in her essay on Gertrude --A Heart Cleft in Twain: the Dilemma of Shakespeare's Gertrude. For a clear understanding of the character of Gertrude, we need to "distinguish between the Gertrude created by Shakespeare and the Gertrude created by the male chauvinist readers". ${ }^{17}$ Smith objects to Gertrude being portrayed by male chauvinistic critics as a 'sex object' full of 'lasciviousness and cunning', and shows that she is actually a simple, affectionate and caring character torn between her loyalty to both Hamlet as her son and Claudius as her husband. She suffers terribly because she cannot act according to Hamlet's desire to give up Claudius, or to turn a blind eye to the sufferings of her son. And in fact Shakespeare portrays Gertrude as possessing abundantly this noble human weakness which prevents one from even thinking of doing any harm to the objects of his love.

Actually, she is convinced that Claudius loves her. She cannot see through the evil motives of Claudius behind his love for her. He tricks her into the marriage by invoking the security of their 'war-like state'. Very shrewdly he presents before everybody that their marriage was essential to show that the royal family remains united despite the death of King Hamlet. He successfully convinces all, especially Gertrude that a split in the royal family would weaken the image of the country to their foreign enemies. Fortinbras's reported threat gives Claudius some credibility. Thus he hides, behind the security concern of the state, his own greed for power. And Gertrude believes in what he says about the marriage before the council and loses all possible apathy for Claudius which is actually replaced by love. And therefore, she finds it too difficult to sacrifice him at the altar of her love for her son. She is so simple and honest that she cannot even imagine that Claudius might turn into such a beast as to murder King Hamlet, or to plan the murder of Hamlet, who, he says, is 'our cousin and our son'. (I ii 116)

The ghost accuses only the 'serpent' Claudius of 'stinging' his life - and seducing his wife. King Hamlet's vengeful passion is purely against Claudius in order that he should immediately lose the crown, while Gertrude can be left to the heavens and to her own conscience. So, Gertrude cannot be accused of consciously betraying her husband which can be attributed to her utter failure to understand depraved, wicked and evil human nature.

On the other hand, Gertrude, unlike Claudius, at no stage admits guilt of any specific crime. When faced with Hamlet's implied accusation,

..............almost as bad, good mother

As kill a king and marry with his brother’

(III. iv 29-30)

She immediately retorts

'As kill a king!'

(III iv 30)

Smith suggests 'she exclaims this in horror: it could be horror or disbelieve at the extraordinary sequence of events.' ${ }^{18}$ On the other hand, Gertrude as far as we are aware, has no knowledge at this stage that Claudius was responsible for her first 


\section{IIUC Studies, Vol. 3}

husband's death - so there is no guilt either on her own account or on Claudius. Having understood Hamlet's professed intention to wring [her] heart. (III. iv. 36). She asks two questions:

'What have I done, that thou dar'st wag thy tongue In noise so rude against me?

and,

Ay me, what act,

That roars so loud and thunderous in the index?

So, clearly there is a vast gap between Hamlet's knowledge and his mother's ignorance of the murder, and it leads to Hamlet's generalization of woman-frailty.

However, the women characters in Hamlet are not representative of all women characters in Shakespearean literature. In the world of Shakespeare we find many strong women characters who can refute the allegations against women based on the weaknesses that Gertrude and Ophelia show. The plays of Shakespeare abound in instances where many remarkably charismatic female characters show unusual strength what was unthinkable in that age. In many of his plays, especially in his comedies, we see women as the dominating characters. In some of his tragedies also we hear their strong voice. For example, Desdemona in Othello is one of the most remarkable female characters of Shakespeare. She is of exceptional physical beauty, of rich parentage, well brought up and refined. A. C. Bradley says: -

"Desdemona, the 'eternal womanly' in its most lovely and adorable form, simple and innocent as a child, ardent with the courage and idealism of a saint, radiant with that heavenly purity of heart which men worship the more because nature so rarely permits it to themselves" 19

She shows a great sense of personality and self-respect in choosing her life-partner. With great confidence she refuses many proposals from many influential Venetians and finally chooses one of her own accord. Again, she is bold enough to leave her parent's house with Othello ignoring the censure of the society. Her boldness originates in her absolute love for Othello. Serajul Islam Choudhury says:-

"Desdemona is not like Ophelia. She may be gentle and kind, but not weak, not at all. Her love is not like that of Rosalind-not love at first sight. It developed gradually, consciously” 20

In the council of the Duke, without showing any timidity or lack of self-confidence, she boldly faces the full court. She convinces all in her favor that her marrying Othello is not an act of rashness, but an action guided by pure and deep love. " I saw Othello's visage in his mind" (I. iii. 255). Although it is a rebellion against society, very firmly she defends her marrying Othello. Her boldness makes her father so surprised that he even cannot believe what she does against the expectation of Venetian society:

Brabantio: “ a maiden never bold;

Of spirit so still and quiet that her motion

Blushed at herself; and she, in spite of nature, 
'Frailty, Thy Name Is Woman' - How Frail are Women in the World of Shakespeare?

Of years, of country, credit, everything,

To fall in love with what she feared to look on"

(I iii $96-100)$

Her profound love makes her bold enough to thwart her father. In an excessively soft voice, she asserts a firm conclusion:

Desdemona:.........my noble father, I do perceive here a divided duty,

To you I am bound for life and education;

My life and education both do learn me

How to respect you. You are the lord of duty;

I am hither to your daughter. But here is my husband,

And so much duty as my mother showed

To you, preferring you before her father,

So much I challenge that I may profess

Due to the Moor, my lord.

(I iii 182-194)

In the Duke's chamber she shows "herself quite as exceptional in the active assertion of her own soul and will”. ${ }^{21}$ The firmness she shows, not even the least frailty, in the council of the duke in defending her action of marrying Othello is unimaginable from a woman in the age of Shakespeare.

Again, at the time of Othello's departure to Cyprus, anticipating that something horrible can happen to her, she refuses to live with her parents; instead, she opts to follow him to Cyprus without being least afraid of facing the danger of war. At Cyprus, although she suffers silently, this is not her weakness rather innocence or inexperience of the wicked world. Her silent suffering can also be interpreted as a silent protest against the wicked world. She idealizes her husband and cannot even think that he can suspect her. Her simplicity makes her think that no woman can be unfaithful to her husband.

Des: tell me Emelia,

That there be women do abuse their husband In such gross kind?

(IV iii 63- 65)

Her sense of purity forbids her to pronounce the word 'whore'. Whore is a taboo for her. ' Am I that name,.......?' (IV ii 124 ) This question is not only to Iago, not even only to herself, but to the society, and readers of all time. With this question she denies all charges to be brought against her in the future. She has always been satisfied and faithful to her husband and sacrificed everything for upholding her love. She unfortunately suffers a lot undeservedly, but never forsakes love. She does not blame any body for her suffering, not even for her death.

She is so deeply in love with Othello that she cannot think of entering any conflict with him. Her love for Othello seems to have contributed to her 'weakness', which ultimately dignifies her in her death. This also happens in the case of Ophelia as well. Hamlet's declaration of love for Ophelia that the love of forty thousand brothers cannot equal his love for her comes after Ophelia's death, showing that she has been accorded a great dignity after death. Martin Orkin says:- 


\section{IIUC Studies, Vol. 3}

"Desdemona is devoted to Othello, admiring and faithful......She does not even know what it means to be unfaithful; the word 'whore' is not in her vocabulary. She is defenseless against the charges brought against her, because she does not even comprehend and cannot believe that anyone would imagine such things. .......Her preferring Othello to her father like Cordelia's placing her duty to a husband before that of a father, is not ungrateful but natural and proper" ${ }^{22}$

What Ophelia fails to do, Desdemona does it successfully. She protests her father's over possessive attitude, at the same time shows respectful gratitude to her father. She is as calculative as Cordelia, putting greater emphasis on her duty towards her husband. Had Ophelia done what Desdemona does, her tragedy and perhaps, that of Hamlet would not have happened. But they all are unique in their respective roles. So we cannot draw a generalized conclusion about all of them based on the role or action of a particular character. Rather we have to understand them by placing them in their respective society. Wilson Knight says: -

"A Shakespearean play is set spatially as well as temporally. ...... the Shakespearian person is intimately fused with this atmospheric quality; he obeys a spatial as well as a temporal necessity". ${ }^{23}$

There are sharp contrasts between Desdemona and her husband. Firstly, she is young, and her husband is in his forties. Secondly, she is white, while her husband is a black moor. Thirdly, she belongs to a Christian society in whose eyes her husband is merely 'a circumcised dog', thus Desdemona has every reason to betray her husband, but she does not. In contrast, there is no age gap between Gertrude and King Hamlet. They both belong to white Christian society. And her husband did every thing to keep her happy. Thus, there is nothing about which she can feel unhappy and think of forgetting her husband so hastily so that prince Hamlet suspects 'a foul play' behind his father's death. To prince Hamlet, her 'hasty marriage' is tantamount to almost a betrayal of her first husband.

Another worth-mentioning Shakespearean woman is Portia in The Merchant of Venice. She is very lively from the very beginning of her appearance in the play. Though at first we notice her lament, she questions the authoritative arrangement of her father, and longs for more free choice.

$$
\text { " I may neither }
$$

Choose who I would nor refuse who I dislike; so is the will of a living daughter curbed by the will of a dead father. Is it not hard, Nerissa, that I cannot choose one nor refuse none?

She is very obedient to the instructions and arrangement of her late father, at the same time she shows great strength of her personality in assessing her suitors. Again, in response to Nerissa's question, she firmly asserts-

$$
\text { ere I will be married to a sponge” }
$$

(I ii 96 - 97)

She dismisses suitor after suitor in a very confident way. Her comments on them are delightfully funny. She shows the firm determination that she will never allow herself to 
be married to 'a sponge' whom she dislikes. "Portia is obedient, it is true, but unlike Ophelia not submissive to her father's will" ${ }^{24}$ She is always very conscious not to show any disrespect to the memory of her dead father. In fact, she passes through a very crucial situation. At one point, she feels like giving Bassanio some hints to choose the right casket, but she refrains herself from doing so because of her moral obligation to her father's arrangement.

$$
\text { “............... I could teach you }
$$

How to choose right, but then I am forsworn.

So will I never be.”

(III ii 11-13)

In fact, Portia is one of Shakespeare's most compelling characters, most memorable, most admired characters. She is always in the centre of the play. Without her presence the play would lose much of its desired effect. She has the wit to befool many male characters in the play.

In the Duke's chamber Portia is very vividly alive. Here Shakespeare allots her one of his most celebrated set speeches. Disguised as a legal expert, she cheerfully tricks Shylock. In fact, Portia's mercy speech is the defining moment in the play. It is the moment when we realize that she is much more intelligent than any one else in the courtroom. Here, she has outwitted Shylock so completely that he has now accepted Portia's authority as an impartial expert. This comment of Shylock is Portia's great moment of triumph. Indeed, there is no other male character in the courtroom who could present the winning arguments. They are not even capable of coming up with the arguments Portia uses. When Antonio is only within a few moments of losing his life, when Bassanio and Gratiano, being upset at Antonio's coming death, both helplessly state that they would gladly sacrifice their beloved wives if doing so could save Antonio's life, it is Portia who manages to save his life by incredibly outsmarting the opponent. She is smarter not only than Shylock, but than her husband also. She outwits him tricking him with their wedding rings. Portia is a woman in the Elizabethan society where gender roles were sharply differentiated, where women were not allowed to go beyond a certain limit, and they are aware of it. Still she transcends that limit. Lady Lee says:-

"But for the most part Shakespeare's comedies ................do contain the subversive message that women are actually smarter than men, but wise enough to keep this a secret” ${ }^{25}$

To Bassanio Portia is

" And she is fair and, fairer than the word

Of wonderous virtue.”

(I i. 162-3)

She is, from Bassanio's male point of view, the perfect woman. Meredith Skura says:-

"Portia is at once spirited and submissive, able to straighten out Venice's legal tangles when all the men have failed and yet ready to call Bassanio her lord” 26

Another striking female character of Shakespeare is Rosalind. Who is 'imaginative, intelligent, emotional, at the same time practical and realistic' ${ }^{27}$ She defies the traditional concept of woman weakness and gives an impression that she may seem to be weak physically but not intellectually, especially in her ready wit. Apprehending dangers from 


\section{IIUC Studies, Vol. 3}

the men folk, she takes disguise to protect Celia and herself. But their apprehension could not prevent them from going to the Forest of Arden. They do not seek help from anywhere; rather they themselves take some measures to befool people who they fear an attack from. Without even stating clearly she depicts men folk as a source of danger. Her extraordinary qualities endear her to all.

At the very first sight Orlando is fascinated by her overwhelming beauty. Only to the envious Duke she is intolerable. Her 'very silence' and 'patience' are so powerful that the duke becomes afraid of them. When the duke banishes her, she does not become scared, rather boldly demands 'the knowledge of my faults' and strongly protests to the duke "Yet your mistrust cannot make me a traitor." My father was no traitor" (I iii 53 61). It shows her loyalty not only to her father, more importantly to the truth itself.

Even Celia has got that much strength to renounce her father, to protest her father's misdeeds. She dares to accompany Rosalind all the way to the Forest of Arden-an unknown, uncertain and insecure place, leaving all the comforts of the court behind and embracing all the difficulties and dangers that may come. She feels a sense of moral obligation to Rosalind for all the wrong deeds of her father to her and the duke senior, and promises to compensate for all these things. "When he dies thou shalt be his heir, for what he hath taken away from thy father perforce, I will render thee again in affection". (I ii. 17-19). She is ashamed of her father's misdeeds. "My father's rough and envious disposition sticks me at heart,”. (I ii 231-2) What she says she actually means it. She rejects and resents her father's act of refusing Orlando's well-deserved reward, only because he is the son of a man whom the duke does not like. Her father tries to persuade Celia that he is doing all these things for her betterment, but all in vain. She opts to go along with Rosalind to the Forest of Arden.

At the court, Celia shows so much strength of character that she almost overshadows even Rosalind. But in the forest Rosalind is the dominating character, the action of the play centers her. In the love scenes almost everything is at her command, even Orlando is meek to her wit. She shows many striking qualities which are unusual for women, but at the same time she exhibits many traits that retain her womanliness very convincingly. Her heart-felt sympathy for the old man and his sons, her losing consciousness at the sight of blood-stained handkerchief bear the testimony to her feminine quality.

As soon as she reaches the forest, she assumes the leading role. Here we find her in her natural potentiality. As Peter Reynolds says 'nature requires nature to thrive. ${ }^{28}$ She teases her lover playfully, outwits him, and tactfully realizes repeated affirmation of his love for her. She has been full of love for Orlando since their very first meeting, but showing a total sense of practicality, conceals her sentiment until it is safe to divulge. She loves Orlando whole-heartedly, but she does not make her love easy-to-get. She preserves her dignity, tests the depth of Orlando's love for her, and very diplomatically obtains the approval of her father. If we take Rosalind as the representative of the women characters of Shakespeare, then the question of Shakespeare's being a misogynist would be totally untenable.

For many obvious reasons, Hamlet shows a misogynistic attitude, but this is not the prevailing feeling in the world of Shakespeare, not even in the world of Hamlet. His own idea about his mother changes in the course of the play. Even to Ophelia, his attitude is tilted more to sympathy than to misogyny. So we should examine and consider all his remarks taking his past attitude and the situation he faces at the moment into account. Instead of doing this, if we conclude that Shakespeare is a misogynist quoting only a few 
'Frailty, Thy Name Is Woman' - How Frail are Women in the World of Shakespeare?

lines from Hamlet, it would be an over generalization without a critical examination.

Considering all the arguments presented in this paper, it can finally be said that women in the world of Shakespeare are not frail in general. Only a few of them show weakness of their character as we find in Hamlet. But, at the same time, we find some very impressively strong women in Shakespeare - as in As You Like It, The Merchant of Venice, Measure for Measure, Othello etc. Shakespeare never intentionally portrays women in a negative light. But his works should be viewed as being a reflection of the world around him. Because a playwright, however individual he is, lives in a society and in spite of his entire individualistic outlook he is not totally free from the outlook of his society. Peter Reynolds observes:-

"Elizabethan society was predominantly patriarchal. Despite the fact that a woman was on the throne, she was, arguably, only nominally there as supreme ruler, as all her close advisers and confidants were men. Women, other than the Queen, had almost no legal rights to an existence which was independent of men. They were regarded firstly as the property of their fathers and after marriage, of their husbands.” ${ }^{29}$

We realize that, though Shakespeare was born and brought up in this male dominated $16^{\text {th }}$ century English society, he seems to have rejected the values upheld by this society about woman. Indeed, he attaches more importance to woman in almost all his plays.

Note:

* All quotations from Serajul Islam Choudhury are in my own translation.

* All quotations of Shakespeare's plays are from The Complete Works of Shakespeare. ed. David Bevington $5^{\text {th }}$ edition, New York: Longman, (2003).

\section{References}

1. Wilson Knight, The Wheel of Fire, London: Routledge classics, (2001), P 20.

2. "too close a blood relation, and yet we are less than kinsmen in that our relationship lacks affection and is indeed unnatural. Hamlet plays on 'kind' as (i)'kindly' and (ii) belonging to nature, suggesting that Claudius is not the same kind of being as the rest of the humanity". Peter D. Holland. University of Notre Dame. Hamlet, Prince of Denmark - . The Complete Works of Shakespeare. ed. David Bevington $5^{\text {th }}$ edition,New York: Longman (2003) p. 1101

3. Ibid. P. 1091

4. Ibid. P. 1091

5. Choudhury, Serajul Islam (1998), Shakespearer Meyra, (Women In Shakespeare), Dhaka: Prachya Vidya Prokashani, p. 48

6. "The popular Elizabethan belief was that spirits such as witches, ghosts, etc. come only when they are summoned, whether by conscious or subconscious mind, and a mind free of any communication with them would never see such things”. Jane E. Howard. Macbeth. The Complete Works of Shakespeare. ed. David Bevington $5^{\text {th }}$ edition, 2003. P. 1255.

7. Knight, Wilson, Ibid. P 21. 


\section{IIUC Studies, Vol. 3}

8. Holland, Peter D., Ibid. P. 1092.

9. Knight, Wilson, Ibid. P 21.

10. Bradley, A.C (1992), Shakespearean Tragedy. Macmillan Education Ltd. (3rd Edition.), p. 111.

11. "Nero - this infamous Roman emperor put his mother, Agrippina, to death because she had murdered her husband Claudius"-- Holland, Peter D., Ibid. p. 1126.

12. Serajul Islam Choudhury, Ibid. p. 50

13. Holland, Peter D., Ibid. p. 1091.

14. Ibid. 1092

15. Choudhury, Serajul Islam (1998), Ibid. p. 50

16. Sharon, Ouditt, Hamlet - Theory in Practice, Explaining Woman's Frailty: Feminist Reading of Gertrude. Ed. Edited By Peter J. Smith and Nigel Wood. Viva Books Private Ltd. New Delhi: (2003) P 89.

17. Ibid.

18. Ibid.

19. Bradley, A.C (1992), Ibid. p. 173

20. Choudhury, Serajul Islam (1998), Ibid. p. 112

21. Bradley, A.C (1992). Ibid. P. 174

22. Orkin, Martin (2003) , University of Haifa. Othello, the Moor of Venice. The Complete Works of Shakespeare. ed. David Bevington. $5^{\text {th }}$ edition, p. 1091.

23. Wilson Knight, Ibid. P 22- 23.

24. Choudhury, Serajul Islam (1998), Ibid. p. 50

25 Lady, Lee (2002), Shakespeare's woman in Drag: Portia, http:www2.hawaii. edu./ lady/lit/Shakespeare/Portia/html.

26 Skura, Meredith (2003), Rice University. The merchant of Venice. The Complete Works of Shakespeare. ed. David Bevington $5^{\text {th }}$ edition, p. 181.

27 Choudhury, Serajul Islam (1998). Ibid. p. 50

28 Reynolds, Peter (1990), Shakespeare. As You Like It. Penguin Critical Studies. Pub: Penguin Group,. p. 9

29. Reynolds, Peter (1990), Ibid. p. 89 